\title{
Teaching Materials of Silent Reading With the OK5R Strategy for Elementary School Students in the Era of Revolution 4.0
}

\author{
Taufina $^{1}$ and Dina Dahliana ${ }^{2}$
}

\begin{abstract}
${ }^{1}$ Doctor in the Department of Basic Education, Universitas Negeri Padang, Indonesia, $\square($ (email) taufina@fip.unp.ac.id ${ }^{2}$ Candidates Master in the Department of Primary School Teacher Education, Universitas Negeri Padang, Indonesia, $\triangle$ (email), dinadahliana23@gmail.com
\end{abstract}

\begin{abstract}
This study aims to develop teaching materials of silent reading with the OK5R strategy in the era of the industrial revolution 4.0 for teacher and grade IV students that are valid, practical, and effective. The development is carried out based on the Plomp (Preliminary Research, Prototyping Phase and Assessment Stage) model that emphasizes the context of needs (educators and students) so as to produce teaching materials for reading silently skill based on the OK5R strategy. Based on the results of the validity trial, it can be seen from the validation of the content, language, presentation, graphic and lesson plans, overall $93.10 \%$ with a very valid category. The practicality of teaching materials is seen from the responses of educators, 98.92\% responses of students is about $96.15 \%$ while the effectiveness of reading silently get the percentage $100 \%$. It can be concluded that the teaching material reading silently using the OK5R strategy developed is appropriate to use in reading silently with the OK5R strategy in grade IV of primary school.
\end{abstract}

Keywords: Reading silently, OK5R, Revolution 4.0

\section{INTRODUCTION}

Education is one of human needs, it will not mean anything if it is not accompanied by continually improving, developing, and innovating sustainable learning (Desyandri, Muhammadi, Mansurdin, \& Fahmi, 2019). One way that can be done in order to achieve that goal is to always look for and find new innovations in the learning process that have an impact on the cultivation of the values of the nation's character and culture. Now, the world changes so rapidly making education as a fundamental. During the 4.0 industrial revolution, the development of information technology has become the basis in human life (Subekt, Taufiq, Susilo, Ibrohim, \& Suwono, 2017). Likewise with the use of a country's curriculum. In the industrial revolution 4.0 in Indonesia a new curriculum was implemented, namely the 2013 curriculum by the Ministry of Education and Culture. Some subjects experience a merger called integrated thematic learning. Integrated thematic learning is learning that integrates various competencies from various subjects into various themes (Puspita, 2016) .

The 2013 curriculum is used an integrated thematic approach of having student books and teacher books. The use of teaching materials is one of the success factors in the learning process. The teaching material used must be in accordance with the criteria so that it will createan effective and fun learning. Oneof focus learning that is considered in integrated thematic learning is
Indonesian. In Indonesian there are four skills namely listening, speaking, reading and writing. One of the four skills that is very important is reading skills. Reading is a process that aims to make students able to know various information from anywhere, so that they can add insight and knowledge, especially when learning in elementary school. There are several techniques of reading. One of reading technique is reading silently. Reading silently must be done with proper reading techniques. The corrected and implemented silent reading technique namely: reading without speaking, lips do not move or mumbling, do not move the head to follow the reading lines, do not point to reading lines with fingers, pencils, or other tools, and do not read words for the sake of words, or sentence by sentence (Muhammadi, Taufina, and Chandra, 2018). In wardly reading in the 2013 curriculum is included in integrated thematic learning because the contents of Indonesian language lessons are used as a deterrent in every subject in the learning process.

In Integrated Thematic Learning where one theme is made to unite several learning contents at once. In general, the implementation of integrated thematic learning has not run optimally because of several problems, such as the teaching materials used do notmake active students. The point is that the activities in learning that exist in teaching materials do not actively involve students. This has an impact on the difficulty of students in understanding the contents of the reading contained in teaching 
materials. This problem is very contrary to the demands of the world of education today. Where, the world of education in the era of the industrial revolution 4.0 is recommended so that it is easy to absorb good information, especially written information. Therefore, teachers are required to prepare appropriate learning strategies so as to increase student participation in learning.

To overcome the problems stated above, it is necessary to develop effective and creative teaching materials that use appropriate strategies. Strategy that can be used is OK5R (Overview, Key ideas, Read, Record, Recite, Review, and Reflect). OK5R is a reading strategy that can help students to investigate, find key ideas, read, record, recite, repeat, and ponder from the contents of the text read (Istarani, 2012:167).

The advantages of the strategy OK5R (Overview, Key ideas, Read, Record, Recite, Review, and Reflect) is this strategy covers a variety of learning and teaching activities, so that the material delivered can be well absorbed by students' knowledge, can help students understand reading comprehensively overall, because while reading students are also required to be able to make important notes from reading material that has been read, students' understanding of reading will be more durable because students are asked to reflect back on the reading text, and can bring out the critical and creative thinking power of students (Istarani, 2012:167).

\section{METHOD}

The development model used in this study is the Plomp (Preliminary Research, Prototyping Phase and Assessment Stage) development model.

1. Preliminary Research (Preliminary Analysis) This preliminary analysis is carried out aimed at defining and defining the learning requirements needed in developing this Teaching Material. The things done at this stage are: (1) Curriculum Analysis, (2) Analysis of student characteristics, (3) Analysis of Teaching Materials used in the field, (4) Analysis of the learning process, (5) Analysis of needs.

2. Prototyping Phase includes: (1) initial draft, (2) prototype 1 , (2) prototype 2 , (3) prototype 3.

3. Assessment Stage.

\section{RESULT AND DISCUSSION}

The development of this research is printed teaching materials in the form of books about reading which are used classically in schools. This teaching material contains about reading skills in the form of books aimed at grade 4 students on the ability to read silently by paying attention to the reading stages. Presentation of data in the research and development of teaching materials reading silently can be divided into 3 types such as: (1) the validity of teaching materials (2) the practicality of teaching materials, (3) the effectiveness of teaching materials, it can be explained as follows:

\section{Teaching Material Validation}

Product validation datawas used a validation sheet in the form of a questionnaire. The data was collected to determine the level of validity / worthiness of teaching materials to read silentlybefore being tested on the field. Product validity conducted by researchers includes: (1) content / material validity, (2) language validity, (3) graphic validity. The explanation of teaching material validation data is as follows:

\section{a. Validation of content eligibility}

Content expert validation was needed as a form of evaluation of the content / material as well as the presentation of products that have been developed. The data obtained in the form of quantitative and qualitative data through a questionnaire given by researcherto experts. Researcherwas provided a content validation questionnaire, and the product developed. Based on the calculation of questionnaire data obtained from validation was about $96.87 \%$ with a very valid category.

b. Language validation

Language validation was needed as an evaluation of the language used in teaching materials that have been developed. The use of effective and communicative language is very important in a teaching material reading silently. Language validity was given to experts in the form of a questionnaire that showed the acquisition of $92.85 \%$ with a very valid category.

c. Validation of presentation aspects

Validation of presentation was needed as an evaluation of the display of instructional materials reading silently. The data obtained in the form of quantitative and qualitative data through a questionnaire provided by researcher to instructional design experts. Based on the calculation of the questionnaire, data obtained from the validation of the design expert, it showed a gain of $93.75 \%$ with a very valid category.

d. Validation of graphics

Validation of graphic was needed as an evaluation of the graphic teaching material in reading silently. The data obtained in the form of quantitative and qualitative data through a questionnaire given by researcher to learning design experts. Based on the calculation of questionnaire data obtained from the validation of the design expert, the acquisition was $90 \%$ with a very valid category.

e. RPP validation

Learning validation was needed as an evaluation of the learning implementation plan. Validity was given to experts in the form of rpp and questionnaires, the data obtained are 85.91 with valid categories.

\section{Practicality of Teaching Materials}

One of the goals to be achieved from this research is to obtain materials a jar silent reading skills based OK5R (Overview, Key ideas, Read, Record, Recite, Review, and Reflect) in Class IV SD practical and 
effective. After being declared practical and effective, it is then carried out in small one-to-one groups followed by small groups and then tested for the effectiveness of teaching materials. The practical level as to see the extent to which teachers and students can use learning tools in the process of learning to read silently based on OK5R ( Overview, Key ideas, Read, Record, Recite, Review, and Reflect) in Class IV Elementary Schools well. According to Plomp (2007: 127) learning tools are said to be practical if the devices can be used easily by teachers and students in the learning process. To see whether the learning tools that have been developed are practical or not, a trial is conducted on class IV students of SDIT Adzikra, West Sumatra. The observed principality was the effectiveness of the lesson plan, the teacher's questionnaire responses and the students' questionnaire responses to the practicality of teaching materials. The results of observations when testing in the field in accordance with the planning that has been made with a percentage of $96.92 \%$ with a very practical category, while the questionnaire of the teacher's response obtained a percentage of $98.29 \%$, with a very practical category and the results of the questionnaire responses of students gained 96.15 with a very practical. This showed that the teaching material to read silently in the thematic using the OK5R strategy that was developed is very practical in the process of learning to read silently in class IV SD.

\section{Effectiveness of teaching materials}

Teaching material was said to be effective if it has a good effect or influence on the achievement of the objectives of the developed teaching material. The effectiveness of students was seen from the learning outcomes of the students in the process of reading silently with OK5R. The results of the data analysis of the activity

Table 1. Aspects and Category

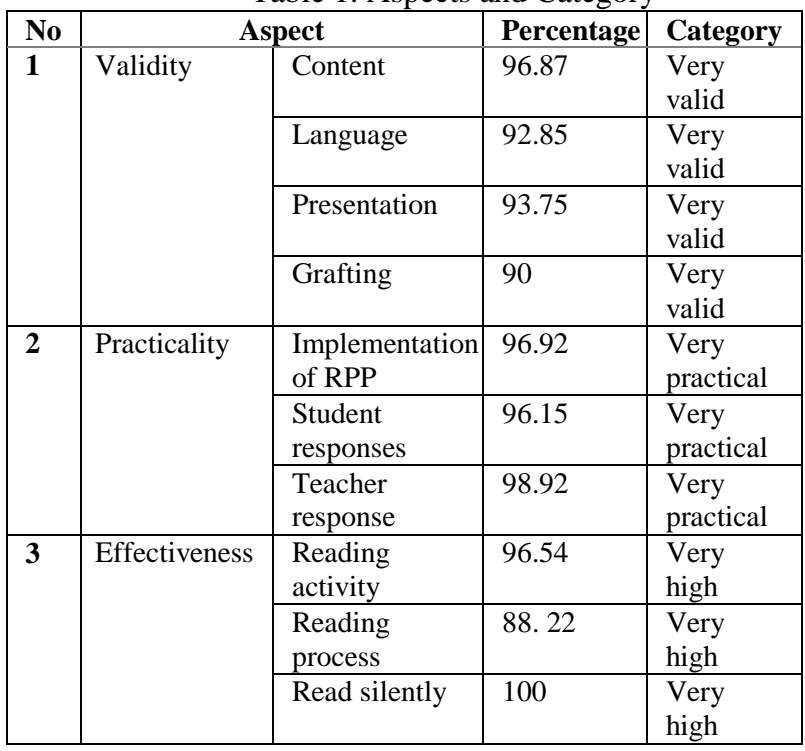

of learners when learning with obtained results of $96.54 \%$ with very highcategory, while the results of the reading silently process obtained $88.28 \%$ with a very high category. While the results of silent reading skills with a percentage of $100 \%$ with very high katerogi. From all observations of students' activities, learning processes, attitudes and giving a very good picture by obtaining a very high percentage, meaning that the use of thematic reading silently materials with the OK5R strategy is very feasible and effective to be disseminated especially in class IV SD. The results of this research can be seen in the table 1 .

\section{CONCLUSIONS}

Based on the development and trials carried out in the field of teachingmaterials in reading silentlywith the OK5R strategy in class IV elementary school, that the development of teaching materials in terms of validity showed that these teaching materials are very valid both in terms of content, language, and construct. The results of this validation have been validated by experts in their respective fields and have been said to be very valid for use. Whereas practicality is categorized as very practical seen from the response of the teacher and students.

The results of the effectiveness of students indicate that the development of teaching materials to read silently using the OK5R strategy in class IV elementary school has been declared effective and has improved reading silently and is very worthy of use. So that this strategy reinforces that the development of instructional materials reading silently with the OK5R strategy is appropriate.

\section{ACKNOWLEDGMENT}

Thank you to Padang State University for helping to facilitate the research conducted from the supervisor to this article.

\section{REFERENCES}

[1] Akker, J.V.D., Bannan,B., Kelly A.E., Nieveen, N., dan Plomp, T. 2007. An Introduction to Educational Design Research. Proceedings of the seminar conducted at the East China Normal University. Shanghai (PR China). November 2326.

[2] Desyandri, D., Muhammadi, M., Mansurdin, M., \& Fahmi, R. (2019). Development of integrated thematic teaching material used discovery learning model in grade $\mathrm{V}$ elementary school. Jurnal Konseling Dan Pendidikan, 7(1), 16. https://doi.org/10.29210/129400

[3] Istarani. (2012). Kumpulan 40 Metode Pembelajaran. Medan: Media Persada.

[4] Mudiono, A., Gipayana, M., \& Madyono, S. (2016). Developing of Integrated Thematic Learning Model through Scientific Approaching with Discovery Learning Technique in Elementary School. International Academic Journal of Social Sciences, 3(10), 19-27. Retrieved from www.iaiest.com 
[5] Muhammadi, Taufina, dan C. (2018). Literasi Membaca Untuk Memantapkan Nilai Sosial Siswa Sd. Litera, 17(2).

[6] Plomp, T., Fauzan, A., \& Gravemeijer, K. 2013. The development of an rme-based geometry course for Indonesian primary schools. In $\mathrm{T}$. Plomp, \& N. Nieveen (Eds.), Educational design research - Part B: Illustrative cases (pp. 159-178). Enschede, the Netherlands: SLO

[7] Puspita, H. J. (2016). Implementasi Pembelajaran Tematik Terpadu Pada Kelas Vb SD Negeri Tegalrejo 1 Yogyakarta. Jurnal Pendidikan Guru Sekolah Dasar, 5(9), 884-893. Retrieved from http://journal.student.uny.ac.id/ojs/index.php/pgsd /article/view/1344

[8] Subekt, H., Taufiq, M., Susilo, H., Ibrohim, I., \& Suwono, H. (2017). Mengembangkan Literasi Informasi Melalui Belajar Berbasis Kehidupan Terintegrasi Stem Untuk Menyiapkan Calon Guru Sains Dalam Menghadapi Era Revolusi Industri 4.0: Revieu Literatur. Education and Human Development Journal, 3(1), 81-90. https://doi.org/10.33086/ehdj.v3i1.90

[9] Taufina, \& Chandra. (2017). Developing the Big Questions and Bookmark Organizers ( Bqbo ) Strategy - Based Literacy Reading Learning Materials in the 4 Th Grade of Elementary School. International Conference for Science Educators and Teachers, 118(5), 857-864. Retrieved from https://www.atlantis-press.com/proceedings/icset$17 / 25886637$

[10] Taufina, T., \& Chandra, C. (2018). The Implication of Authentic Assessment in Thematic Integrated Learning Process at Lower Level Elementary School Early Childhood Development. Advances in Social Science, Education and Humanities Research (ASSEHR) International Conference of Early Childhood Education (ICECE 2017), 169(February). https://doi.org/10.2991/icece-17.2018.36

[11] Yusna, H. (2012). Peningkatan Kemampuan Mencari Kalimat Utama Dengan Strategi Overview, Key Ideas, Read, Record, Recite, Review, And Reflect (OK5R) Pada Pelajaran Bahasa Indonesia Siswa Kelas IV Madrasah Ibtidaiyah Negeri Merangin Kecamatan Bangkinang B 